\title{
Completing Autophagy: Formation and Degradation of the Autophagic Body and Metabolite Salvage in Plants
}

\author{
Szymon Stefaniak ${ }^{1}$, tukasz Wojtyla ${ }^{1}\left(\mathbb{D}\right.$, Małgorzata Pietrowska-Borek $^{2} \mathbb{(}$ and \\ Sławomir Borek $1, *$ (D) \\ 1 Department of Plant Physiology, Faculty of Biology, Adam Mickiewicz University Poznań, Uniwersytetu \\ Poznańskiego 6, 61-614 Poznań, Poland; szymon.stefaniak@amu.edu.pl (S.S.); wojtylal@amu.edu.pl (Ł.W.) \\ 2 Department of Biochemistry and Biotechnology, Faculty of Agronomy and Bioengineering, \\ Poznań University of Life Sciences, Dojazd 11, 60-632 Poznań, Poland; \\ malgorzata.pietrowska-borek@up.poznan.pl \\ * Correspondence: borek@amu.edu.pl
}

Received: 24 February 2020; Accepted: 20 March 2020; Published: 23 March 2020

\begin{abstract}
Autophagy is an evolutionarily conserved process that occurs in yeast, plants, and animals. Despite many years of research, some aspects of autophagy are still not fully explained. This mostly concerns the final stages of autophagy, which have not received as much interest from the scientific community as the initial stages of this process. The final stages of autophagy that we take into consideration in this review include the formation and degradation of the autophagic bodies as well as the efflux of metabolites from the vacuole to the cytoplasm. The autophagic bodies are formed through the fusion of an autophagosome and vacuole during macroautophagy and by vacuolar membrane invagination or protrusion during microautophagy. Then they are rapidly degraded by vacuolar lytic enzymes, and products of the degradation are reused. In this paper, we summarize the available information on the trafficking of the autophagosome towards the vacuole, the fusion of the autophagosome with the vacuole, the formation and decomposition of autophagic bodies inside the vacuole, and the efflux of metabolites to the cytoplasm. Special attention is given to the formation and degradation of autophagic bodies and metabolite salvage in plant cells.
\end{abstract}

Keywords: Atg proteins; autophagosome; tonoplast; vacuole; SNARE proteins

\section{Introduction}

Autophagy, which literally means "self-eating", plays a crucial role in the degradation of useless or damaged cell components such as macromolecules, protein complexes, and organelles. Autophagy also plays a role in the degradation of foreign elements for cells, such as bacteria, viruses or sperm residues after egg cell fertilization. It is a conserved process that occurs in a similar way in fungal, animal and plant cells. This process was first observed in the 1960s, and for decades it was thought to involve non-selective degradation of cellular elements [1-3]. However, the results of studies performed in the last three decades reveal that autophagy is a highly advanced and specific process necessary for the proper functioning of the cell [4]. Under normal conditions, autophagy occurs at low intensity, but as a result of various abiotic and biotic stress factors (e.g., carbon or nitrogen starvation, salinity, drought, high temperature, reactive oxygen species or pathogens) the process is dramatically intensified [5-11]. In mammals, autophagy plays an important role during normal growth and development, starting from early embryogenesis [12]. It is important for maintaining good health because its efficient operation prevents the development of many diseases, including cancer, diseases of the liver, muscles, and heart, neurodegenerative diseases (e.g., Huntington's disease), inflammation, pathogen infections, 
and aging [13-19]. In plants, autophagy participates in the circulation of cell components and acts as a quality control mechanism. It also functions in some developmental processes such as pollen maturation, aging, and cell death, including programmed cell death [6,7,20-23].

Some stages of autophagy are currently subject to intensive study, and our knowledge is gradually increasing. Areas of strong research interest include the initiation of autophagy, formation and elongation of the phagophore, and identification of the receptors and scaffold proteins involved in selective kinds of autophagy. However, despite many years of research, some aspects of autophagy are still not fully understood. Our knowledge about some stages of autophagy is poor, even fragmentary, and in addition, these stages are currently not of interest to many scientists. These include the final stages of autophagy, in particular, the degradation of autophagic bodies and the recovery of metabolites constituting the final products of autophagy. We specifically focus on the formation and degradation of autophagic bodies and metabolite salvage in plant cells and we compare this knowledge to data related to yeast.

\section{Formation of the Autophagic Body during Macroautophagy}

\subsection{Formation and Trafficking of Autophagosome}

Macroautophagy is by far the best-studied and described type of autophagy. The first visible symptom of macroautophagy is the appearance in the cytoplasm of a cup-shaped structure, called the phagophore (Figure 1). The phagophore elongates, surrounding and simultaneously separating the fragment of the cytoplasm together with organelles or other components of the cell that are intended for degradation. The final stage of phagophore differentiation is the complete surrounding of the cargo and its sequestration inside the autophagosome. This is a vesicle with a double, bilayer lipid-protein membrane, containing cargo intended for autophagic degradation [24-29]. The mechanisms of these initial stages have been intensively studied and described in numerous review papers, e.g., [30-33]. In yeast and plants, the autophagosome fuses with the vacuole creating an autophagic body that is quickly degraded by vacuolar lytic enzymes [34-37]. In animals, the autophagic body is not formed because autophagosome fuses with the lysosome, which delivers lytic enzymes enabling the degradation of the cargo inside the autolysosome (Figure 1) [29,38].

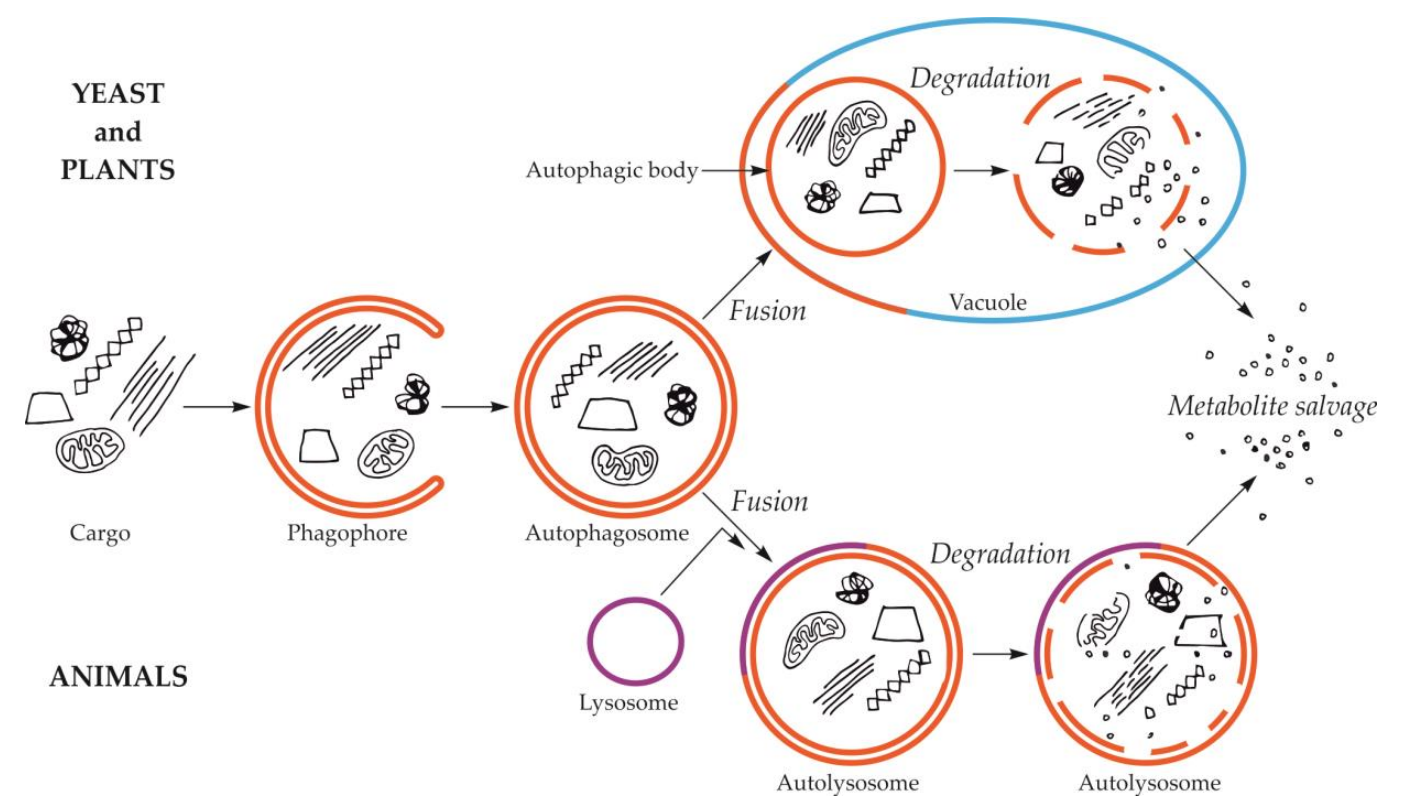

Figure 1. Schematic diagram of macroautophagy in cells of yeast and plants (upper part of the drawing) and in cells of animals (bottom part of the drawing). In yeast and plant cells, the autophagosome fuses to the tonoplast, creating the autophagic body inside the vacuole. In animal cells, the autophagosome fuses with the lysosome, giving the autolysosome. The autophagic body inside the vacuole and the content of autolysosome are rapidly degraded, allowing reuse of metabolites. 
Components of the cytoskeleton play an important role in the cytoplasmic transport of autophagosomes [39]. It is also suggested that the cytoplasmic transport of autophagosomes is enabled by the microtubule network controlled by endosomal sorting complexes required for transport (ESCRT) [25]. The occurrence of ESCRT was evidenced in yeast [40,41] and plants [42,43]. An important role in this transport is played by fully developed autophagosomes with the outer-membrane-anchored Atg8 and phosphatidylinositol 3-phosphate (PI3P) in yeast (Figure 2, Table 1) and plants (Figure 3, Table 1) [44-48]. The protein FYCO1 (FYVE and coiled-coil domain-containing protein 1) is also important in the association of the autophagosome membrane and microtubules, and it has a modular structure composed of four amino acid domains and spiral signaling domain FYVE [46,49]. Due to its structure, FYCO1 interacts with the autophagosome surface simultaneously in two places-with Atg8 and PI3P (both in yeast and plants). These two sites for recognition and linking of the autophagosome with the FYCO1 make it possible to distinguish between mature autophagosomes and phagophores [46,50,51] because only on the surface of the mature autophagosomes are there simultaneously proteins necessary to form stable and double bonds with FYCO1. Attached to the surface of the autophagosome, FYCO1 also binds to GTP-binding protein 7 (Ypt7) in yeast and Ras-related protein RAB7 (RAB7) in plants [49,52,53], creating an autophagosome-FYCO1-Ypt7/RAB7 system that allows the binding of the autophagosome to microtubules. The autophagosome-FYCO1-Ypt7/RAB7 system moves to the plus end of microtubules by the binding of Ypt7/RAB7 to the kinesin motor proteins [52,54].

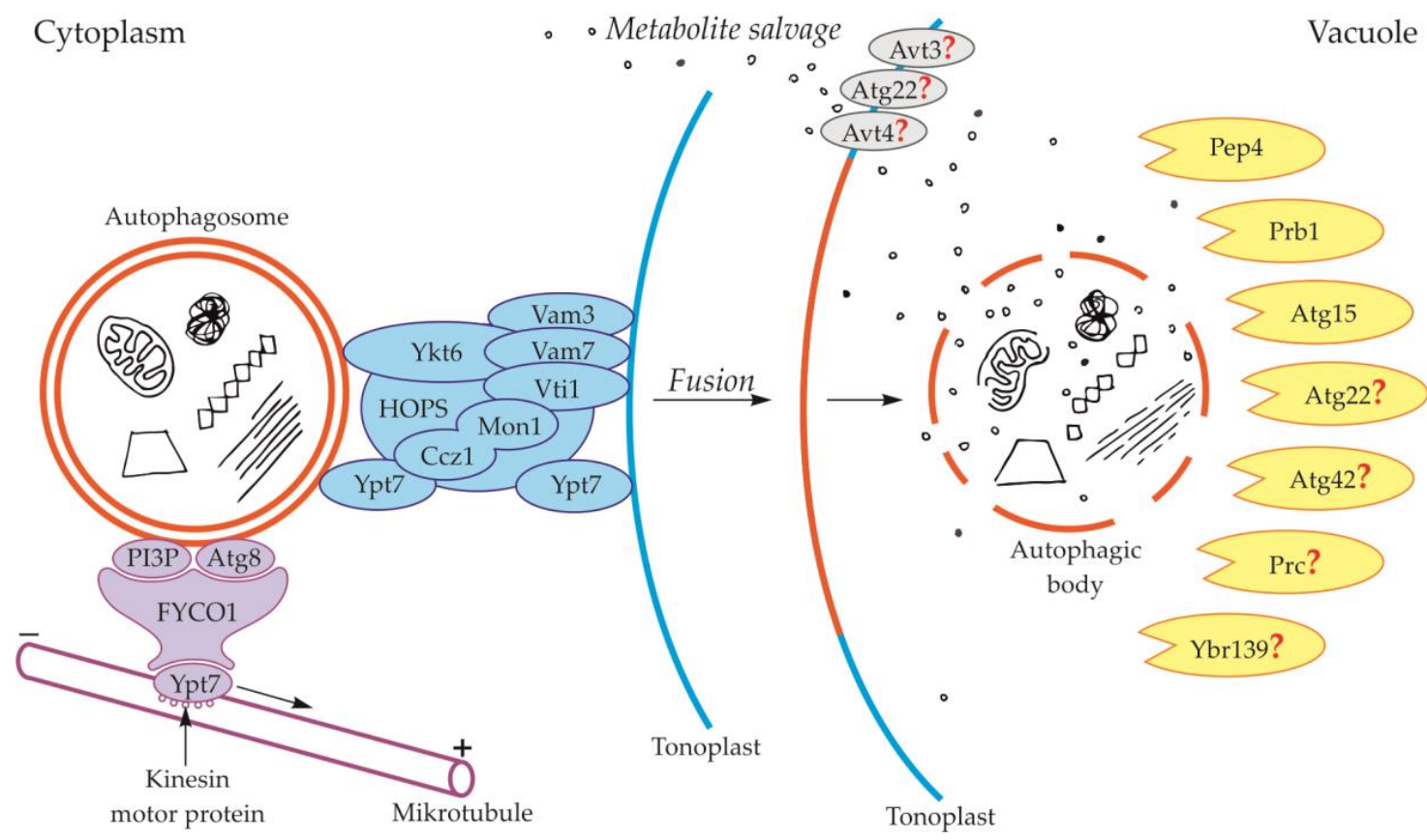

Figure 2. Schematic diagram depicting trafficking and fusion of the autophagosome to the vacuole and degradation of the autophagic body inside the vacuole in yeast. PI3P and Atg8 anchored in the outer membrane of the autophagosome are involved in autophagosome trafficking and bind autophagosome with FYVE and coiled-coil domain-containing protein 1 (FYCO1). The complex autophagosome-FYCO1-Ypt7 moves along microtubules in the direction of the plus end by the binding of Ypt7 to kinesin motor proteins. Proteins Vam3, Vam7, Vti1, Ykt6, Ypt7, and complexes Ccz1-Mon1 and HOPS are involved in the fusion of the autophagosome and vacuole. The newly formed autophagic body inside the vacuole is rapidly degraded by lytic enzymes. Proteins involved in the degradation of the autophagic body are proteinase A (Pep4), proteinase B (Prb1), and putative lipase Atg15. Other proteins that are probably involved in the degradation of the autophagic body are Atg22, Atg42, Prc, and Ybr139. It is suggested that Atg22, Avt3, and Avt4 are involved in metabolite efflux from the vacuole to the cytoplasm. Question marks indicate the hypothetical involvement of proteins in the degradation of the autophagic body and metabolite efflux from the vacuole to the cytoplasm. 


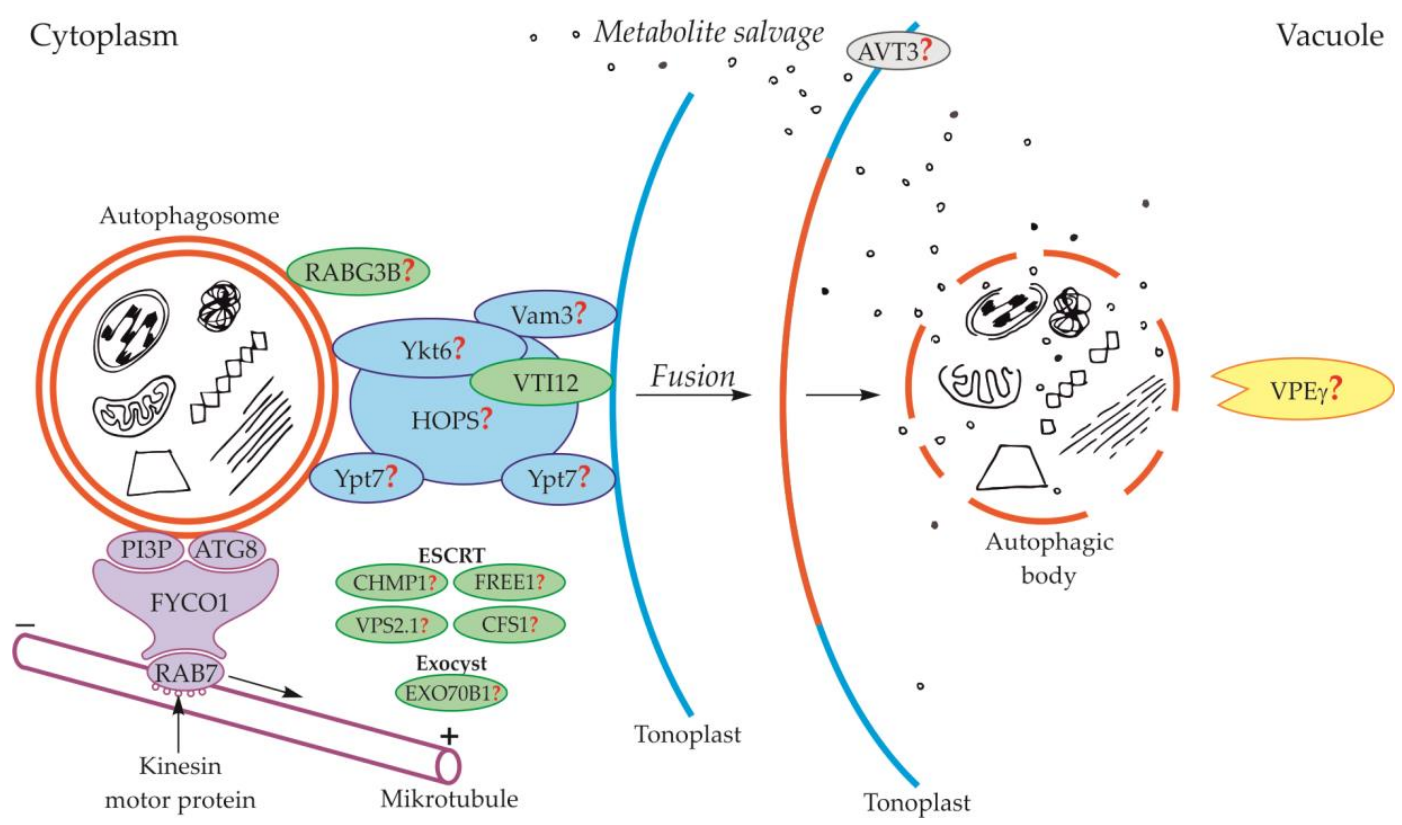

Figure 3. Schematic diagram depicting trafficking and fusion of the autophagosome to the vacuole and the degradation of the autophagic body inside the vacuole in plants. PI3P and ATG8 anchored in the outer membrane of the autophagosome are involved in autophagosome trafficking and bind autophagosome with FYCO1 protein. The complex autophagosome-FYCO1-RAB7 moves along microtubules in the direction of the plus end by the binding of RAB7 to kinesin motor proteins. Protein VTI12 is involved in the fusion of the autophagosome and vacuole. RABG3B is located on the surface of the autophagosome but the involvement of this protein in the fusion of the autophagosome and vacuole in plants remains unclear. It is suggested that the homologous yeast proteins Ykt6, Vam3, Ypt7, and complex HOPS are involved in the fusion of autophagosome and vacuole in plants. Additionally, it is suggested that plant proteins CHMP1, FREE1, VPS2.1, CFS1, and the complex EXO70B1 are involved in the autophagosome trafficking, autophagosome-vacuole fusion, and the release of the autophagic body into the vacuole lumen. The newly formed autophagic body inside the vacuole is rapidly degraded by lytic enzymes. One of them can be the vacuolar processing enzyme $\gamma$ (VPE $\gamma)$. Proteins involved in metabolite efflux from the vacuole to the cytoplasm during autophagy in plants have not been described so far. Only permease AVT3 was confirmed in Arabidopsis thaliana, but the involvement of this permease in the transport of metabolites coming from the degradation of the autophagic body is not confirmed. Question marks indicate the hypothetical involvement of plant proteins and complexes, or plant homologs of yeast proteins, during autophagy.

\subsection{Fusion of the Autophagosome with the Vacuole and Formation of the Autophagic Body}

During the fusion of the autophagosome with the vacuole in yeast, the outer membrane of the autophagosome is connected and incarnated to the tonoplast, while the inner membrane together with the content becomes the autophagic body inside the vacuole (Figure 1, Figure 2) [24,25,55,56]. In yeast, during fusion, protein Ypt7 and complex HOPS are involved (Figure 2, Table 1) [57,58]. Ypt7 is involved in autophagy in Magnaporthe oryzae, Pichia pastoris, Saccharomyces cerevisiae, and Schizosaccharomyces pombe [59-65]. Ypt7 is recruited to the surface of the autophagosome by the interaction with the calcium caffeine zinc sensitivity 1-monensin sensitivity 1 complex (Ccz1-Mon1), which is the Ypt7 guanine nucleotide exchange factor. Furthermore, in the fusion of the autophagosome and tonoplast in yeast such proteins as cis-Golgi membrane traffic (Vti1) [66], syntaxin VAM3 (Vam3) [67], syntaxin VAM7 (Vam7) [68-70], and Ykt6 are involved (Figure 2, Table 1) [58,71-73].

In plants, the fusion of autophagosome and vacuole and the mechanisms regulating this process are poorly understood. So far, only the involvement of protein VTI12 has been confirmed in the fusion of autophagosome and vacuole in plants (Figure 3, Table 1). This protein belongs to the complex named 
soluble N-ethylmaleimide-sensitive factor activating protein receptors (SNARE proteins). Plant VTI12 is the ortholog of yeast Vti1 (Figure 2, Table 1). In Arabidopsis mutants with T-DNA VTI12 insertion, growing in rich-nutrient conditions, presented a normal phenotype, whereas under nutrient-poor conditions accelerated aging was observed, confirming that VTI12 is involved in autophagy in plants [25,74-77]. This protein also participates in the transport of storage proteins from the cytoplasm to the vacuole [76]. Although plants express many SNARE proteins that are involved in a variety of processes such as defense against pathogen attack [78] or intracellular transport [79], VTI12 is the only SNARE protein that has been proven to be involved in the fusion of the autophagosome and vacuole in plants (Figure 3, Table 1). Other protein that may be involved in the fusion of autophagosome and vacuole in plants is RABG3B (Figure 3, Table 1). So far, the occurrence of RABG3B has been confirmed in Arabidopsis and Populus and it participates in, among other processes, the formation of the wood conductive elements when programmed cell death occurs $[80,81]$. The protein RABG3B is located at the surface of the autophagosome, however, it remains unclear whether RABG3B can regulate the fusion of the autophagosome and vacuole in plants. It is suggested that the homologous yeast proteins such as Ykt6, Vam3, Ypt7, and complex HOPS are involved in the fusion of autophagosome and vacuole in plants $[46,82]$. Moreover, it is also suggested that the plant components of the ESCRT complex, such as the charged multi-vesicular body protein 1 (CHMP1), FYVE-domain protein required for endosomal sorting 1 (FREE1), vacuolar protein sorting 2.1 (VPS2.1), cell death-related endosomal FYVE/SYLF protein 1 (CFS1), and plant exocyst complex component EXO70B1 (EXO70B1) are involved in trafficking of the autophagosome, the fusion of autophagosome and vacuole, and the release of the autophagic body into the vacuole [25]. Nevertheless, the detailed localization and function of these proteins and complexes are not known.

Table 1. Proteins involved, or hypothetically involved, in trafficking and fusion of the autophagosome to the vacuole and formation of the autophagic body during macroautophagy.

\begin{tabular}{|c|c|c|c|}
\hline Protein & Organism & Function & References \\
\hline PI3P, Atg8 & $\begin{array}{l}\text { yeast, } \\
\text { plant }\end{array}$ & autophagosome trafficking and fusion & {$[46,47]$} \\
\hline Vti1 & yeast & autophagosome formation, autophagosome-vacuole fusion & {$[66]$} \\
\hline Ykt6 & yeast & $\begin{array}{l}\text { retrograde transport, vacuole homotypic fusion, vesicles and } \\
\text { vacuole fusion }\end{array}$ & [71-73] \\
\hline Vam3 & yeast & $\begin{array}{l}\text { endosome-autophagosome fusion, autophagosome } \\
\text { maturation, autophagosome-vacuole docking and fusion }\end{array}$ & {$[66,67,70]$} \\
\hline Vam7 & yeast & autophagosome-vacuole fusion & [68-70] \\
\hline Ccz1-Mon1, Ypt7 & yeast & autophagosome-vacuole fusion & {$[59,63]$} \\
\hline \multirow{2}{*}{ HOPS } & yeast & autophagosome-vacuole fusion & {$[57,58]$} \\
\hline & plant & probably autophagosome-vacuole fusion & {$[46,82]$} \\
\hline VTI12 & plant & $\begin{array}{l}\text { probably autophagosome formation, docking, and } \\
\text { autophagosome-vacuole fusion, storage protein transport } \\
\text { from cytoplasm to vacuole }\end{array}$ & [74-77] \\
\hline RABG3B & plant & $\begin{array}{l}\text { autophagy enhancement during xylem development and } \\
\text { pathogen-induced cell death, probably autophagosome } \\
\text { formation and autophagosome-vacuole fusion }\end{array}$ & {$[78,79]$} \\
\hline $\begin{array}{l}\text { CHMP1, FREE1, } \\
\text { VPS2.1, CFS1, } \\
\text { EXO70B1 }\end{array}$ & plant & $\begin{array}{l}\text { probably autophagic trafficking, autophagosome-vacuole } \\
\text { fusion, release of autophagic body }\end{array}$ & [25] \\
\hline
\end{tabular}

\section{Formation of the Autophagic Body during Microautophagy}

The amount of data in the literature that describes the process of microautophagy in fungi, animals and plants, including its course, regulation mechanisms, and importance for the cell, is much smaller than the information on macroautophagy. During microautophagy, an autophagosome is not formed, 
but the tonoplast creates an invagination into which the cargo moves. The invagination of the tonoplast increases and the cargo is engulfed into the vacuole forming an autophagic body (Figure 4) [83-85]. Microautophagy can also occur through the formation of an arm-shaped protrusion of the tonoplast when a portion of the cytoplasm is captured into the vacuole (Figure 4). So far, the formation of the protrusion has been confirmed for microautophagic degradation of peroxisomes in Pichia pastoris and degradation of anthocyanin aggregates in Arabidopsis thaliana [86,87]. However, the best-known mechanism of microautophagy is the absorption of the cargo into the vacuole by membrane invagination. It occurs as a result of changes in the organization of the structure of the vacuolar membrane, mainly through changes in the content of lipids and large transmembrane proteins [88]. The membrane is invaginated, and the speed and extent of these changes are regulated in yeast by Vps1p [89] (Table 2). Environmental factors, such as carbon or nitrogen starvation, also have a significant influence on the process of membrane differentiation, formation of an invagination, and the subsequent formation of an autophagic tube and autophagic body $[88,90]$. The formation of the autophagic tube in yeast is an ATP-dependent process [91]. Moreover, the processes of membrane differentiation and formation of the autophagic tube and autophagic body are regulated by numerous Atg proteins and signaling complexes. Two Atg7-dependent ubiquitin-like conjugation systems (UBLC) are involved in the regulation of microautophagy. The first of these consists of Atg8 coupled with phosphatidylethanolamine (Atg8-PE) by Atg7 as an E1-like enzyme and Atg3 as an E2-like enzyme. Moreover, in this UBLC system, cysteine protease Atg4 proteolytically removes the C-terminal of Atg8 [92,93]. The second UBLC system includes Atg12 covalently linked to Atg 5 through a ubiquitin-dependent conjugation system consisting of Atg7 as an E1-like enzyme, and Atg10 as an E2-like enzyme. The Atg12-Atg5 dimer oligomerizes with Atg16 to stimulate the formation of the Atg8-PE complex [94,95]. Furthermore, the Atg7-dependent UBLC system, called the vacuolar transporter chaperone (VTC) complex, plays an important role in the formation of the autophagic tube in yeast by controlling the distribution of proteins in different regions of the membrane $[89,96]$. In addition, the VTC complex is a potential site for calmodulin activation and thus initiation of membrane invagination. Calmodulin is a factor stimulating tonoplast invagination during microautophagy and the formation of the autophagic tube. The top of the autophagic tube expands to form a pre-vesicular structure. The autophagic tube and the pre-vesicular structure are formed based on sorting mechanisms and differences in the density of proteins and lipids occurring in the structure of the autophagic tube. The newly formed vesicles expand due to the action of E1 and E2-like enzymes, and then bud from the end of the tube, forming the autophagic body inside the vacuole $[89,97]$.
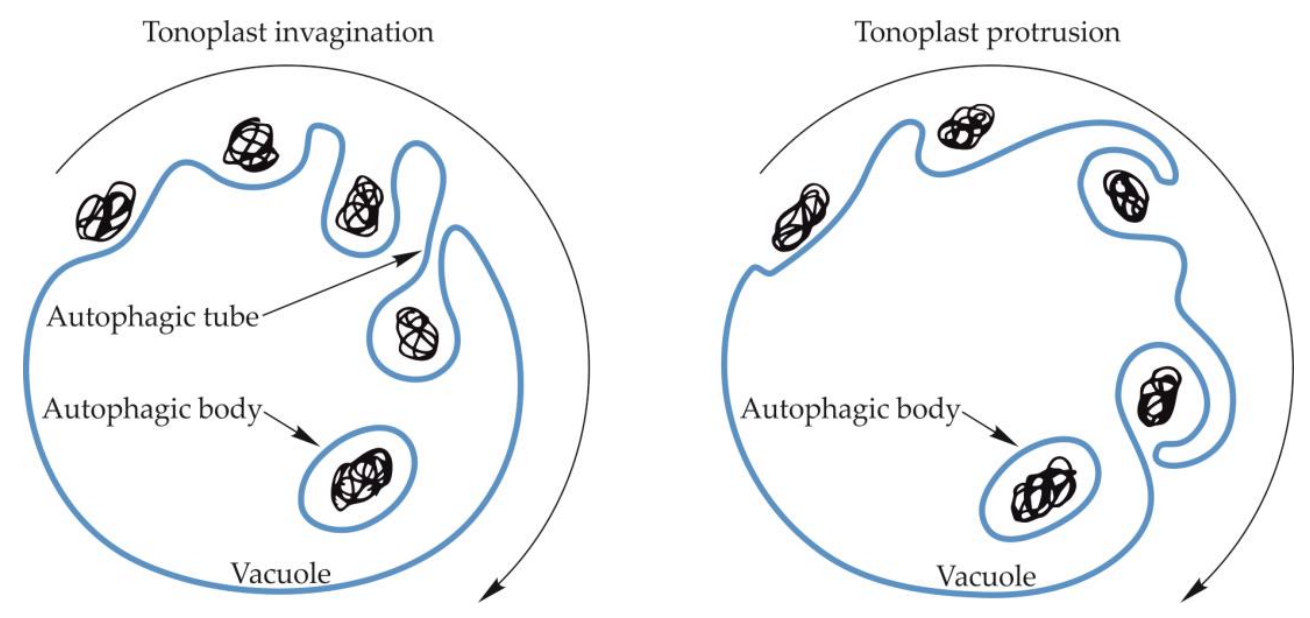

Figure 4. Schematic diagram of microautophagy in yeast and plants. Microautophagy may occur by vacuolar membrane invagination, which increases, creating the autophagic tube in yeast, and the cargo is enclosed inside the vacuole, forming a vesicle surrounded by a single two-layer membrane-an autophagic body. The occurrence of the autophagic tube in plants has not been confirmed. The autophagic body may also be formed by an arm-shaped protrusion of the tonoplast capturing a cargo into the vacuole. 
Microautophagy, similarly to macroautophagy, can occur in a selective manner. One example of selective microautophagy is micropexophagy - an autophagic degradation of peroxisomes [98]. During micropexophagy peroxisomes are surrounded by an arm-shaped protrusion of vacuole membrane, the vacuolar sequestering membranes (VSM). It is suggested that the key structure involved in the formation of VSM is a perivacuolar structure (PVS), which is a structure similar to the pre-autophagosomal structure (PAS) in yeast macroautophagy. Moreover, PVS participates in the formation of the micropexophagy-specific membrane apparatus (MIPA) [99]. MIPA is also a key structure necessary for the complete surrounding peroxisomes intended for degradation during micropexophagy. MIPA is a double-membrane, small, cup-shaped structure whose fusion with VSM closes the peroxisomes inside the vacuole [100-102]. Inside the vacuole, a single-membrane vesicle containing peroxisomes is released, and the forming autophagic body is called a micropexophagic body. In contrast to macroautophagy, proteins Atg1, Atg11, Atg26, Atg28, Atg30, and Atg35 are necessary for microautophagy to occur in Pichia pastoris. It has been suggested that these proteins play a role in the early stages of microautophagy such as recognition and mobilization of peroxisomes intended for autophagic degradation [102,103]. Proteins Atg3, Atg4, Atg7, Atg8, Atg26, Atg28, and Atg30 are involved in the formation of MIPA [100,103-106]. Proteins specific for VSM formation during micropexophagy are Atg11, Atg17, Atg30, and Atg37 [105,107] (Table 2). Another type of selective microautophagy is micromitophagy, i.e., autophagic degradation of mitochondria. Micromitophagy occurs by transferring mitochondria from the cytoplasm to the lumen of the vacuole by invagination of the vacuolar membrane $[88,90,108,109]$. The increasing invagination of the vacuolar membrane engulfs the mitochondria intended for degradation and forms an autophagic tube. At the end of the autophagic tube, the mitochondria-containing autophagic body is formed. Two UBLC systems, kinase-Atg1, Atg9, Atg11, Vac8, and Vam7 are involved in micromitophagy in yeast $[108,110]$ (Table 2). In addition to micropexophagy and micromitophagy, the piecemeal microautophagy of the nucleus $(\mathrm{PMN})$ is described as a selective type of microautophagy. This is the autophagic degradation of a part of the cell nucleus. This process is initiated by the fusion of membranes of the cell nucleus and vacuole. The tonoplast protein Vac8 and protein Nvj1, being a part of the nuclear envelope, are involved in the fusion [111] (Table 2). The next stage is the formation of tonoplast invagination that increases and transforms into an intra-vacuolar vesicle consisting of three membranes (tonoplast and two nuclear envelope membranes) and a portion of the nucleoplasm. After the formation of the intra-vacuolar vesicle, the cell nucleus and vacuole separate and the autophagic body is formed. Effective degradation of nuclear elements during PMN requires the expression of core Atg genes [112,113]. However, the participation of Atg proteins seems to be limited to the final stages of this process, namely, the stage of the detachment of a fragment of the cell nucleus and closing of the tonoplast [114].

Table 2. Proteins involved in the formation of the autophagic body during microautophagy.

\begin{tabular}{cccc}
\hline Protein & Organism & Function & References \\
\hline Vps1p & yeast & $\begin{array}{c}\text { regulation of vacuole membrane } \\
\text { invagination }\end{array}$ & [89] \\
\hline $\begin{array}{c}\text { Atg12, Atg5, } \\
\text { Atg10, Atg16 }\end{array}$ & yeast & $\begin{array}{c}\text { differentiation of vacuole membrane, } \\
\text { formation of autophagic tube, autophagic } \\
\text { body formation }\end{array}$ & [92-95] \\
\hline $\begin{array}{c}\text { Atg3, Atg4, Atg7,Atg8, } \\
\text { Atg26, Atg28, Atg30 }\end{array}$ & yeast & $\begin{array}{c}\text { formation of the micropexophagy-specific } \\
\text { membrane apparatus (MIPA) during } \\
\text { micropexophagy }\end{array}$ & {$[100,103-106]$} \\
\hline Atg11, Atg17, Atg37 & yeast & $\begin{array}{c}\text { formation of the vacuolar sequestering } \\
\text { membranes during micropexophagy }\end{array}$ & {$[102,105]$} \\
\hline Vac8, Nvj1 & yeast & fusion of cell nucleus and vacuole & {$[111]$} \\
\hline
\end{tabular}




\section{Degradation of the Autophagic Body and Metabolite Efflux from the Vacuole to the Cytoplasm}

Only a few publications describe the degradation of the autophagic body and is often written about using generalities, predictions, and suggestions. The degradation is rapid and begins immediately after its appearance inside the vacuole. Compared to the initial stages of autophagy, the mechanism and regulation of the degradation of the autophagic body and the efflux of metabolites from the vacuole to the cytoplasm are very poorly investigated and understood. However, these are key stages on the path to recycling cellular components in the entire autophagy process.

Proteins involved in the degradation of the autophagic body in yeast are proteinase A (Pep4) and proteinase B (Prb1) (Figure 2, Table 3). These proteins are involved in the activation of cascades of other vacuolar proteases and hydrolases, which are indicated as key factors involved in the degradation of the autophagic body in yeast $[34,115,116]$. However, the cascades involved in autophagic body degradation have not yet been identified in detail. The best-known and described protein involved in the degradation of the autophagic body in yeast is Atg15, a putative lipase (Figure 2, Table 3). It has been proven that this protein plays a role in the degradation of the autophagic body, not only through the decomposition and recycling of components of the autophagic body membrane but also due to it being a key protein involved in the degradation of the cargo located inside the autophagic body [34,117-120]. In addition to those described above, there are several other proteins that are thought to be involved in the degradation of the autophagic body in yeast, but their mechanism of action and functions are not yet fully understood. Proteins whose participation in the degradation of the autophagic body has not yet been undeniably confirmed are Atg22, Atg42, Ybr139, and Prc [121-123] (Figure 2, Table 3). After the degradation of the autophagic body, the metabolites must be transported to the cytoplasm. Unfortunately, there is minimal knowledge available about this stage of autophagy. It is thought that the putative vacuolar permease Atg22 is the protein that may be responsible for this transport. This protein may cooperate with two other vacuolar permeases Avt3 and Avt4 [123-125], which mediate the transport of leucine and other amino acids from the vacuole to the cytoplasm [123-126]. Nevertheless, the involvement of Avt3 and Avt4 in the transport of amino acids derived from the degradation of the autophagic body during autophagy in yeast is still hypothetical (Figure 2, Table 3) [123-125].

So far, in plants, the events occurring during and after the degradation of the autophagic body inside the vacuole are poorly understood. Only one protein has been described in plants that is likely to be involved in the degradation of the autophagy body. The VPE $\gamma$ protein described in Arabidopsis thaliana is likely to act similarly to yeast Pep4 by activating cascades of other hydrolases that are responsible for the hydrolysis of various structures found inside vacuoles, including the autophagic body (Figure 3 , Table 3) [127]. However, these hydrolases are not precisely indicated. In the literature, there are no reports of plant proteins being involved in the efflux of metabolites released during the degradation of the autophagic body from the vacuole to the cytoplasm. Only the existence of vacuolar permease AVT3 was confirmed in Arabidopsis thaliana [128], but it is not known how important this permease is in the transport of metabolites coming from the degradation of the autophagic body in plants. 
Table 3. Proteins involved, or hypothetically involved, in the degradation of the autophagic body and metabolite efflux from the vacuole to the cytoplasm during macroautophagy.

\begin{tabular}{|c|c|c|c|}
\hline Protein & Organism & Function & References \\
\hline $\begin{array}{l}\text { Pep4 } \\
\text { (Proteinase A), } \\
\text { Prb1 } \\
\text { (Proteinase B) }\end{array}$ & yeast & $\begin{array}{l}\text { activation of protease and hydrolase cascades by } \\
\text { proteolytic processing }\end{array}$ & {$[34,115,116]$} \\
\hline Atg15, & yeast & $\begin{array}{l}\text { degradation of autophagic body, decomposition } \\
\text { and recycling of autophagic body membrane, } \\
\text { proaminopeptidase I maturation }\end{array}$ & {$[34,117-120]$} \\
\hline $\operatorname{Atg} 22$ & yeast & $\begin{array}{l}\text { tonoplast protein with limited homology to } \\
\text { permeases, putative vacuolar transporter involved } \\
\text { in the efflux of metabolites from the vacuole to the } \\
\text { cytoplasm }\end{array}$ & {$[122,123]$} \\
\hline $\begin{array}{l}\text { Atg42, Ybr139, } \\
\text { Prc1 }\end{array}$ & yeast & probably degradation of the autophagic body & [56] \\
\hline Avt3, Avt4 & yeast & $\begin{array}{l}\text { vacuolar efflux transporters potentially involved in } \\
\text { the efflux of leucine and other amino acids derived } \\
\text { from the degradation of the autophagic body }\end{array}$ & [123-126] \\
\hline $\mathrm{VPE} \gamma$ & $\begin{array}{l}\text { Arabidopsis } \\
\text { thaliana }\end{array}$ & $\begin{array}{l}\text { probably autocatalytically converted into a smaller } \\
\text { active form, which, like yeast's Pep4, might be } \\
\text { involved in proteolytically downstream processes } \\
\text { that are responsible for the degradation of various } \\
\text { vacuolar constituents }\end{array}$ & [127] \\
\hline AVT3 & $\begin{array}{l}\text { Arabidopsis } \\
\text { thaliana }\end{array}$ & $\begin{array}{l}\text { vacuolar efflux transporter potentially involved in } \\
\text { the efflux of metabolites derived from the } \\
\text { degradation of the autophagic body }\end{array}$ & [128] \\
\hline
\end{tabular}

\section{Regulation of Autophagic Body Degradation}

The regulation of the whole autophagy process is an extensive topic, which has been intensively studied for several decades. In short, autophagy under normal conditions occurs at a low intensity; however, this process is clearly enhanced as a result of various types of abiotic and biotic stresses mboxciteB29-ijms-741503,B129-ijms-741503,B130-ijms-741503,B131-ijms-741503. In yeast, the main factors that increase the intensity of autophagy are carbon, nitrogen and phosphate starvation [24,129]. In plants, it is known that carbon or nitrogen starvation significantly increases the intensity of autophagy $[7,24,29,36,132,133]$. In yeast, animal and plant cells, mTOR kinase is the main intracellular center of signal collection associated with autophagy. Amino acids are involved in the activation of mTOR kinase, which apart from autophagy regulates such processes as growth, proliferation, cell movement, and protein translation [134-136]. It has also been proven that autophagy plays a key role in maintaining the level of free amino acids in the cell and protein synthesis under stress [137], but it has not been explained how amino acids as one of the end products of autophagy regulate this process. Furthermore, in contrast to the well-known mechanisms regulating autophagy in general, surprisingly little is known about the regulation of the degradation of the autophagic body, which is one of the final stages of autophagy. So far in plants, it has only been observed that the degradation of the autophagic body is clearly inhibited by asparagine during sugar starvation-induced autophagy in cells of lupin (Lupinus spp.) embryo axes during seed germination [133]. Enhanced autophagy was found in sugar-starved cells of lupin embryo axes, which was evidenced, among other things, by a high degree of vacuolization and a clear decrease in phosphatidylcholine content $[133,138,139]$. Under such conditions, the autophagic bodies were rapidly degraded and they were not observed in the enlarged vacuoles. Nevertheless, asparagine, a central amino acid in the metabolism of germinating protein lupin seeds [140], caused clear inhibition in the degradation of autophagic bodies and their 
accumulation in highly enlarged vacuoles. Such accumulation of autophagic bodies inside enlarged vacuoles proves that asparagine only inhibits the degradation of autophagic bodies, but does not reduce the intensity of autophagy in general. The effect of asparagine is similar to the action of concanamycin A (an inhibitor that slows down the breakdown of the autophagic body by lowering the $\mathrm{pH}$ of the vacuole); however, the mechanism of the inhibitory action of asparagine is not known [133].

\section{Conclusions and Future Perspectives}

Research on autophagy is currently being carried out in many research centers around the world and is the focus of interest for many research teams. The research on autophagy has two faces. On one hand, the initial stages of autophagy, selective types of autophagy and its significance in the etiology, course, and prevention of diseases is being studied intensively, while on the other hand, there are still many aspects of autophagy that are not popular among the scientific community. The events occurring in the final stages of autophagy have been explored only marginally and require a lot of research to be fully understood. Knowledge regarding the formation and, in particular, degradation of the autophagic body is sparse. Also, the efflux of metabolites from the vacuole to the cytoplasm is poorly investigated and understood. These stages of autophagy have not been intensively studied, indeed, they have been analyzed somewhat incidentally and are often written about using generalities and conjecture. Nevertheless, these latter stages are very important stages, because they complete the entire process of autophagy. Although autophagy has been known since the 1960s, and in the last two or three decades our knowledge on autophagy has increased dramatically, there are still many unanswered questions. For example, is the autophagic body degraded by nonspecific vacuolar lytic enzymes, or is the autophagic body degraded by some specific autophagy-related enzymes? Or do both of these enzymes participate in the degradation of the autophagic body? Another poorly understood stage of autophagy in plants is the transport of metabolites from the vacuole to the cytoplasm after autophagic body degradation. Also, in this case, there are other unanswered questions such as whether the constitutive vacuolar membrane transporters are involved in the transport of metabolites to the cytoplasm or whether some autophagy-related transporters are necessary for the metabolite salvage at the end of autophagy. It is also unknown whether, and how the spectrum and level of vacuolar lytic enzymes and membrane transporters change during enhanced autophagy occurring under different stresses, for example, during carbon or nitrogen starvation. In summary, so far, we have only discovered the tip of the iceberg and there remains much to be explored on the way to a full understanding of the whole process of autophagy.

Author Contributions: S.S. wrote the majority of the manuscript and co-designed all figures; Ł.W. and M.P.-B. were involved in the writing of the manuscript; S.B. conceived the topic of the article, was involved in the writing of the manuscript, co-designed and drew all figures. All authors read and approved the final version of the manuscript.

Funding: This work was financed by the National Science Centre, Poland (grant no. 2016/23/B/NZ3/00735).

Conflicts of Interest: The authors declare no conflict of interest.

$\begin{array}{ll}\text { Abbreviations } \\ \text { Atg } & \text { Autophagy related proteins } \\ \text { Avt } & \text { Amino acid vacuolar transporter } \\ \text { Ccz1-Mon1 } & \text { Calcium caffeine zinc sensitivity 1-monensin sensitivity 1 complex } \\ \text { ESCRT } & \text { Endosomal sorting complexes required for transport } \\ \text { FYCO1 } & \text { FYVE (Zinc finger FYVE) and coiled-coil domain-containing protein 1 } \\ \text { HOPS } & \text { Homotypic vacuole fusion and protein sorting } \\ \text { MIPA } & \text { Micropexophagy-specific membrane apparatus } \\ \text { mTOR } & \text { Serine/threonine-protein kinase mTOR } \\ \text { Nvj1 } & \text { Nucleus-vacuole junction protein 1 } \\ \text { PAS } & \text { Phagophore assembly site or Pre-autophagosomal structures } \\ \text { Pep4 } & \text { Proteinase A }\end{array}$




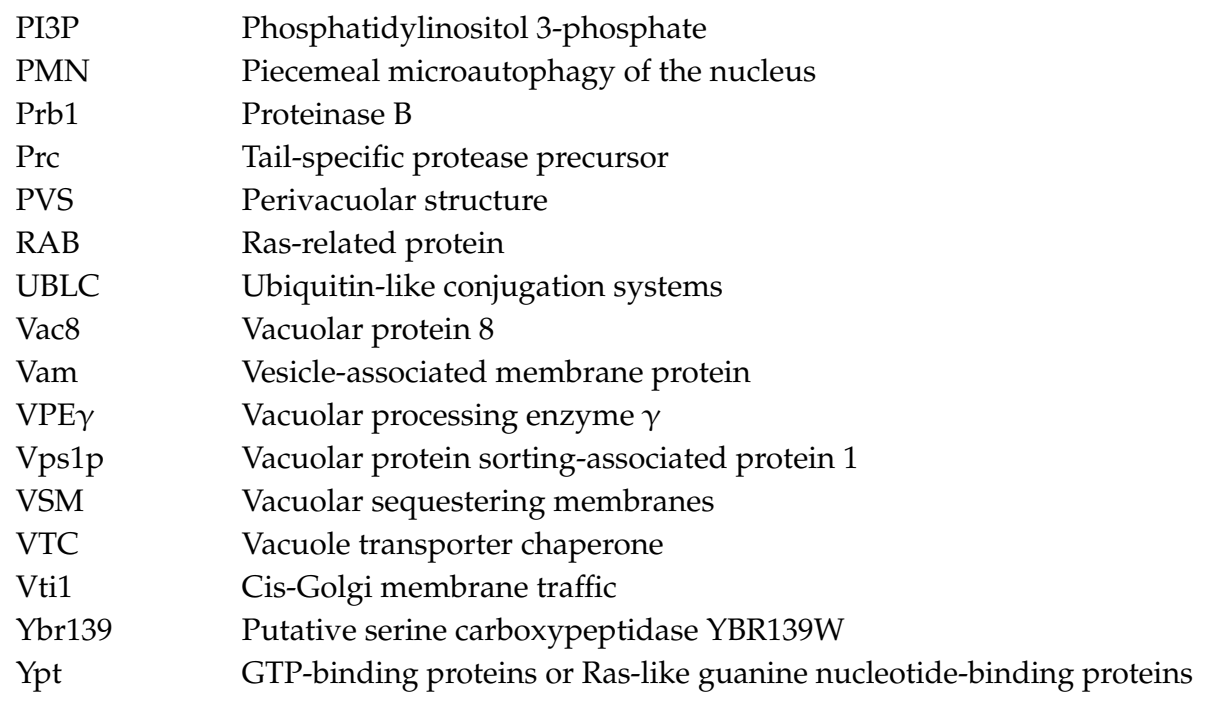

\section{References}

1. Ashford, T.P.; Porter, K.R. Cytoplasmic components in hepatic cell lysosomes. J. Cell Biol. 1962, 12, $198-202$. [CrossRef]

2. Deter, R.L.; Baudhuin, P.; De Duve, C. Participation of lysosomes in cellular autophagy induced in rat liver by glucagon. J. Cell Biol. 1967, 35, 11-16. [CrossRef] [PubMed]

3. Deter, R.L.; De Duve, C. Influence of glucagon, an inducer of cellular autophagy, on some physical properties of rat liver lysosomes. J. Cell Biol. 1967, 33, 437-449. [CrossRef]

4. Gatica, D.; Lahiri, V.; Klionsky, D.J. Cargo recognition and degradation by selective autophagy. Nat. Cell Biol. 2018, 20, 233-242. [CrossRef]

5. He, C.; Klionsky, D.J. Regulation mechanisms and signaling pathways of autophagy. Annu. Rev. Genet. 2009, 43, 67-93. [CrossRef] [PubMed]

6. Floyd, B.E.; Morriss, S.C.; MacIntosh, G.C.; Bassham, D.C. What to eat: Evidence for selective autophagy in plants. J. Integr. Plant Biol. 2012, 54, 907-920. [CrossRef] [PubMed]

7. Lv, X.; Pu, X.; Qin, G.; Zhu, T.; Lin, H. The roles of autophagy in development and stress responses in Arabidopsis thaliana. Apoptosis 2014, 19, 905-921. [CrossRef]

8. Pei, D.; Zhang, W.; Sun, H.; Wei, X.; Yue, J.; Wang, H. Identification of autophagy-related genes ATG4 and ATG8 from wheat (Triticum aestivum L.) and profiling of their expression patterns responding to biotic and abiotic stresses. Plant Cell Rep. 2014, 33, 1697-1710. [CrossRef]

9. Zhou, J.; Wang, J.; Yu, J.-Q.; Chen, Z. Role and regulation of autophagy in heat stress responses of tomato plants. Front. Plant Sci. 2014, 5, 174. [CrossRef]

10. Mizushima, N.; Klionsky, D.J. Protein turnover via autophagy: Implications for metabolism. Annu. Rev. Nutr. 2007, 27, 19-40. [CrossRef]

11. Tang, J.; Bassham, D.C. Autophagy in crop plants: What's new beyond Arabidopsis? Open Biol. 2018, 8, 180162. [CrossRef] [PubMed]

12. Sato, M.; Sato, K. Dynamic regulation of autophagy and endocytosis for cell remodeling during early development. Traffic 2013, 14, 479-486. [CrossRef] [PubMed]

13. Towers, C.G.; Wodetzki, D.; Thorburn, A. Autophagy and cancer: Modulation of cell death pathways and cancer cell adaptations. J. Cell Biol. 2019, 6, 219. [CrossRef] [PubMed]

14. Cai, Q.; Jeong, Y.Y. Mitophagy in Alzheimer's disease and other age-related neurodegenerative diseases. Cells 2020, 9, 150. [CrossRef] [PubMed]

15. Yang, Y.; Klionsky, D.J. Autophagy and disease: Unanswered questions. Cell Death Differ. 2020. [CrossRef] [PubMed]

16. Kaushal, G.P.; Chandrashekar, K.; Juncos, L.A.; Shah, S.V. Autophagy function and regulation in kidney disease. Biomolecules 2020, 10, 100. [CrossRef]

17. Badadani, M. Autophagy mechanism, regulation, functions, and disorders. ISRN Cell Biol. 2012, $2012,927064$. [CrossRef] 
18. Ding, Q.; Bao, J.; Zhao, W.; Hu, Y.; Lu, J.; Chen, X. Natural autophagy regulators in cancer therapy: A review. Phytochem. Rev. 2014, 14, 137-154. [CrossRef]

19. Ochaba, J.; Lukacsovich, T.; Csikos, G.; Zheng, S.; Margulis, J.; Salazar, L.; Steffan, J.S. Potential function for the Huntingtin protein as a scaffold for selective autophagy. Proc. Natl. Acad. Sci. USA 2014, 111, 16889-16894. [CrossRef]

20. Rudnicka, K.W.; Szczęsna, E.; Miszczyk, E.; Mikołajczyk-Chmiela, M. Apoptosis and autophagy-Mechanisms and detection methods. Adv. Cell Biol. 2011, 38, 247-265.

21. Hanamata, S.; Kurusu, T.; Kuchitsu, K. Roles of autophagy in male reproductive development in plants. Front. Plant Sci. 2014, 5, 457. [CrossRef] [PubMed]

22. Khan, M.S.; Hemalatha, S. Autophagy: Molecular insight and role in plant programmed cell death and defense mechanism. Int. Res. J. Biol. Sci. 2015, 4, 78-83.

23. Fan, J.; Yu, L.; Xu, C. Dual role for autophagy in lipid metabolism in Arabidopsis. Plant Cell 2019, 31, $1598-1613$. [CrossRef] [PubMed]

24. Reggiori, F.; Klionsky, D.J. Autophagic processes in yeast: Mechanism, machinery and regulation. Genetics 2013, 194, 341-361. [CrossRef] [PubMed]

25. Marshall, R.S.; Vierstra, R.D. Autophagy: The master of bulk and selective recycling. Annu. Rev. Plant Biol. 2018, 69, 173-208. [CrossRef]

26. Bozhkov, P.V. Plant autophagy: Mechanisms and functions. J. Exp. Bot. 2018, 69, 1281-1285. [CrossRef]

27. Ding, X.X.; Zhang, M.; Otegui, S. Plant autophagy: New flavors on the menu. Curr. Opin. Plant Biol. 2018, 46, 113-121. [CrossRef]

28. Puri, C.; Vicinanza, M.; Rubinsztein, D.C. Phagophores evolve from recycling endosomes. Autophagy 2018, 14, 1475-1477. [CrossRef]

29. Klionsky, D.J.; Abdelmohsen, K.; Abe, A.; Abedin, M.J.; Abeliovich, H.; Acevedo, A.; Adachi, H.; Adams, C.M.; Adams, P.D.; Adeli, K.; et al. Guidelines for the use and interpretation of assays for monitoring autophagy (3rd edition). Autophagy 2016, 12, 1-222. [CrossRef]

30. Avin-Wittenberg, T.; Baluška, F.; Bozhkov, P.V.; Elander, P.H.; Fernie, A.R.; Galili, G.; Batoko, H. Autophagy-related approaches for improving nutrient use efficiency and crop yield protection. J. Exp. Bot. 2018, 14, 1335-1353. [CrossRef]

31. Søreng, K.; Neufeld, T.P.; Simonsen, A. Membrane trafficking in autophagy. In International Review of Cell and Molecular Biology; Galluzzi, L., Ed.; Elsevier Inc.: Amsterdam, The Netherlands, 2018; Volume 336, pp. 1-92.

32. Morishita, H.; Mizushima, N. Diverse cellular roles of autophagy. Annu. Rev. Cell Dev. Biol. 2019, 6, 453-475. [CrossRef]

33. Khandia, R.; Dadar, M.; Munjal, A.; Dhama, K.; Karthik, K.; Tiwari, R.; Chaicumpa, W. A comprehensive review of autophagy and its various roles in infectious, non-infectious, and lifestyle diseases: Current knowledge and prospects for disease prevention. Cells 2019, 8, 674. [CrossRef] [PubMed]

34. Torggler, R.; Papinski, D.; Kraft, C. Assays to monitor autophagy in Saccharomyces cerevisiae. Cells 2017, 6, 23. [CrossRef] [PubMed]

35. Farré, J.C.; Subramani, S. Mechanistic insights into selective autophagy pathways: Lessons from yeast. Nat. Rev. Mol. Cell Biol. 2016, 17, 537-552. [CrossRef] [PubMed]

36. Liu, Y.; Bassham, D.C. Autophagy: Pathways for Self-Eating in Plant Cells. Annu. Rev. Plant Biol. 2012, 63, 215-237. [CrossRef]

37. Masclaux-Daubresse, C.; Chen, Q.; Havé, M. Regulation of nutrient recycling via autophagy. Curr Opin Plant Biol. 2017, 39, 8-17. [CrossRef]

38. Shen, H.M.; Mizushima, N. At the end of the autophagic road: An emerging understanding of lysosomal functions in autophagy. Trends. Biochem. Sci. 2014, 39, 61-71. [CrossRef] [PubMed]

39. Monastyrska, I.; Rieter, E.; Klionsky, D.J.; Reggiori, F. Multiple roles of the cytoskeleton in autophagy. Biol. Rev. Camb. Philos. Soc. 2009, 84, 431-448. [CrossRef]

40. Brune, T.; Kunze-Schumacher, H.; Kölling, R. Interactions in the ESCRT-III network of the yeast Saccharomyces cerevisiae. Curr. Genet. 2019, 65, 607-619. [CrossRef]

41. Yang, Y.; Liu, Q.; Jiang, G.; Chen, S.; Zhou, L.; Sakamoto, N.; Yao, F. Genome-wide screen reveals important roles for ESCRT proteins in drug/ion resistance of fission yeast. PLoS ONE 2018, 13, e0198516. [CrossRef]

42. Winter, V.; Hauser, M.T. Exploring the ESCRTing machinery in eukaryotes. Trends Plant Sci. 2006, 11, 115-123. [CrossRef] [PubMed] 
43. Gao, C.; Zhuang, X.; Cui, Y.; Fu, X.; He, Y.; Zhao, Q.; Jiang, L. Dual roles of an Arabidopsis ESCRT component FREE1 in regulating vacuolar protein transport and autophagic degradation. Proc. Natl. Acad. Sci. USA 2015, 112, 1886-1891. [CrossRef] [PubMed]

44. Bassham, D.C. Plant autophagy-More than a starvation response. Curr. Opin. Plant Biol. 2007, 10, 587-593. [CrossRef] [PubMed]

45. Obara, K.; Noda, T.; Niimi, K.; Ohsumi, Y. Transport of phosphatidylinositol 3-phosphate into the vacuole via autophagic membranes in Saccharomyces cerevisiae. Genes Cells 2008, 13, 537-547. [CrossRef] [PubMed]

46. Li, F.; Vierstra, R.D. Autophagy: A multifaceted intracellular system for bulk and selective recycling. Trends Plant Sci. 2012, 17, 526-537. [CrossRef]

47. Xu, H.; Wickner, W.T. N-terminal domain of vacuolar SNARE Vam7p promotes trans-SNARE complex assembly. Proc. Natl. Acad. Sci. USA 2012, 109, 17936-17941. [CrossRef]

48. McEwan, D.G.; Popovic, D.; Gubas, A.; Terawaki, S.; Suzuki, H.; Stadel, D.; Dikic, I. PLEKHM1 regulates autophagosome-lysosome fusion through HOPS complex and LC3/GABARAP proteins. Mol. Cell 2015, 57, 39-54. [CrossRef]

49. Pankiv, S.; Alemu, E.A.; Brech, A.; Bruun, J.A.; Lamark, T.; Øvervatn, A.; Johansen, T. FYCO1 is a Rab7 effector that binds to LC3 and PI3P to mediate microtubule plus end-directed vesicle transport. J. Cell Biol. 2010, 188, 253-269. [CrossRef]

50. Jager, S. Role for Rab7 in maturation of late autophagic vacuoles. J. Cell Sci. 2004, 117, 4837-4848. [CrossRef]

51. Gutierrez, M.G.; Munafo, D.B.; Beron, W.; Colombo, M.I. Rab7 is required for the normal progression of the autophagic pathway in mammalian cells. J. Cell Sci. 2004, 117, 2687-2697. [CrossRef]

52. Pankiv, S.; Johansen, T. FYCO1: Linking autophagosomes to microtubule plus end-directing molecular motors. Autophagy 2010, 6, 550-552. [CrossRef] [PubMed]

53. Lőrincz, P.; Kenéz, L.A.; Tóth, S.; Kiss, V.; Varga, Á.; Csizmadia, T.; Simon-Vecsei, Z.; Juhász, G. Vps8 overexpression inhibits HOPS-dependent trafficking routes by outcompeting Vps41/Lt. Elife 2019, 8, e45631. [CrossRef] [PubMed]

54. Nordmann, M.; Ungermann, C.; Cabrera, M. Role of rab7/ypt7 in organizing membrane trafficking at the late endosome. Rab GTPases and Membrane Trafficking. Curr. Biol. 2018, 28, 132-143.

55. Parzych, K.R.; Ariosa, A.; Mari, M.; Klionsky, D.J. A newly characterized vacuolar serine carboxypeptidase, Atg42/Ybr139w, is required for normal vacuole function and the terminal steps of autophagy in the yeast Saccharomyces cerevisiae. Mol. Biol. Cell. 2018, 29, 1089-1099. [CrossRef]

56. Segev, N. Ypt and Rab GTPases: Insight into functions through novel interactions. Curr. Opin. Cell Biol. 2001, 13, 500-511. [CrossRef]

57. Reggiori, F.; Ungermann, C. Autophagosome Maturation and Fusion. J. Mol. Biol. 2017, 429, $486-496$. [CrossRef]

58. Bas, L.; Papinski, D.; Licheva, M.; Torggler, R.; Rohringer, S.; Schuschnig, M.; Kraft, C. Reconstitution reveals Ykt6 as the autophagosomal SNARE in autophagosome-vacuole fusion. J. Cell Biol. 2018, 217, 3656-3669. [CrossRef]

59. Liu, X.H.; Chen, S.M.; Gao, H.M.; Ning, G.A.; Shi, H.B.; Wang, Y.; Lin, F.C. The small GTPase MoYpt7 is required for membrane fusion in autophagy and pathogenicity of Magnaporthe oryzae. Environ. Microbiol. 2015, 17, 4495-4510. [CrossRef]

60. Polupanov, A.S.; Nazarko, V.Y.; Sibirny, A.A. CCZ-MON1 and YPT7genes are involved in pexophagy, the Cvt pathway and non-specific macroautophagy in the methylotrophic yeast Pichia pastoris. Cell Biol. Int. 2011, 35, 311-319. [CrossRef]

61. Mukaiyama, H.; Nakase, M.; Nakamura, T.; Kakinuma, Y.; Takegawa, K. Autophagy in the fission yeast Schizosaccharomyces pombe. FEBS Lett. 2010, 584, 1327-1334. [CrossRef]

62. Van Zutphen, T.; Todde, V.; de Boer, R.; Kreim, M.; Hofbauer, H.F.; Wolinski, H.; Kohlwein, S.D. Lipid droplet autophagy in the yeast Saccharomyces cerevisiae. Mol. Biol. Cell. 2014, 25, 290-301. [CrossRef] [PubMed]

63. Nordmann, M.; Cabrera, M.; Perz, A.; Bröcker, C.; Ostrowicz, C.; Engelbrecht-Vandré, S.; Ungermann, C. The Mon1-Ccz1 complex is the GEF of the late endosomal Rab7 homolog Ypt7. Curr. Biol. 2010, 20, 1654-1659. [CrossRef] [PubMed]

64. Gerondopoulos, A.; Langemeyer, L.; Liang, J.R.; Linford, A.; Barr, F.A. BLOC-3 Mutated in Hermansky-Pudlak syndrome is a Rab32/38 guanine nucleotide exchange factor. Curr. Biol. 2012, 22, 2135-2139. [CrossRef] [PubMed] 
65. Kiontke, S.; Langemeyer, L.; Kuhlee, A.; Schuback, S.; Raunser, S.; Ungermann, C.; Kümmel, D. Architecture and mechanism of the late endosomal Rab7-like Ypt7 guanine nucleotide exchange factor complex Mon1-Ccz1. Nat. Commun. 2017, 8, 14034. [CrossRef]

66. Ishihara, N.; Hamasaki, M.; Yokota, S.; Suzuki, K.; Kamada, Y.; Kihara, A.; Ohsumi, Y. Autophagosome requires specific early Sec proteins for its formation and NSF/SNARE for vacuolar fusion. Mol. Biol. Cell 2001, 12, 3690-3702. [CrossRef]

67. Darsow, T.; Rieder, S.E.; Emr, S.D. A multispecificity syntaxin homologue, Vam3p, essential for autophagic and biosynthetic protein transport to the vacuole. J. Cell Biol. 1997, 138, 517-529. [CrossRef]

68. Sato, T.K.; Darsow, T.; Emr, S.D. Vam7p, a SNAP-25-like molecule, and Vam3p, a syntaxin homolog, function together in yeast vacuolar protein trafficking. Mol. Cell. Biol. 1998, 18, 5308-5319. [CrossRef]

69. Ward, D.M.; Pevsner, J.; Scullion, M.A.; Vaughn, M.; Kaplan, J. Syntaxin 7 and VAMP-7 are soluble $\mathrm{N}$-ethylmaleimide-sensitive factor attachment protein receptors required for late endosome-lysosome and homotypic lysosome fusion in alveolar macrophages. Mol. Biol. Cell 2000, 11, 2327-2333.

70. Fader, C.M.; Sanchez, D.G.; Mestre, M.B.; Colombo, M.I. TI-VAMP/VAMP7 and VAMP3/cellubrevin: Two v-SNARE proteins involved in specific steps of the autophagy/multivesicular body pathways. Biochim. Biophys. Acta 2009, 1793, 1901-1916. [CrossRef]

71. Dilcher, M.; Köhler, B.; von Mollard, G.F. Genetic interactions with the yeast Q-SNARE VTI1 reveal novel functions for the R-SNARE YKT6. J. Biol. Chem. 2001, 14, 34537-34544. [CrossRef]

72. Kweon, Y.; Rothe, A.; Conibear, E.; Stevens, T.H. Ykt6p is a multifunctional yeast R-SNARE that is required for multiple membrane transport pathways to the vacuole. Mol. Biol. Cell. 2003, 14, 1868-1881. [CrossRef] [PubMed]

73. Klionsky, D.J. The molecular machinery of autophagy: Unanswered questions. J. Cell. Sci. 2005, 118, 7-18. [CrossRef] [PubMed]

74. Surpin, M. The VTI Family of SNARE proteins is necessary for plant viability and mediates different protein transport pathways. Plant Cell 2003, 15, 2885-2899. [CrossRef] [PubMed]

75. Surpin, M.; Raikhel, N. Traffic jams affect plant development and signal transduction. Nat. Rev. Mol. Cell Biol. 2004, 5, 100-109. [CrossRef]

76. Sanmartin, M.; Ordonez, A.; Sohn, E.J.; Robert, S.; Sanchez-Serrano, J.J.; Surpin, M.A.; Rojo, E. Divergent functions of VTI12 and VTI11 in trafficking to storage and lytic vacuoles in Arabidopsis. Proc. Natl. Acad. Sci. USA 2007, 104, 3645-3650. [CrossRef]

77. Bourdais, G.; McLachlan, D.H.; Rickett, L.M.; Zhou, J.; Siwoszek, A.; Häweker, H.; Robatzek, S. The use of quantitative imaging to investigate regulators of membrane trafficking in Arabidopsis stomatal closure. Traffic 2019, 20, 168-180. [CrossRef]

78. Zhang, Z.; Feechan, A.; Pedersen, C.; Newman, M.A.; Qiu, J.; Olesen, K.L.; Thordal-Christensen, H. A SNARE-protein has opposing functions in penetration resistance and defence signalling pathways. Plant J. 2007, 49, 302-312. [CrossRef]

79. Uemura, T.; Ueda, T. Plant vacuolar trafficking driven by RAB and SNARE proteins. Curr. Opin. Plant Biol. 2014, 22, 116-121. [CrossRef]

80. Kwon, S.I.; Cho, H.J.; Jung, J.H.; Yoshimoto, K.; Shirasu, K.; Park, O.K. The Rab GTPase RabG3b functions in autophagy and contributes to tracheary element differentiation in Arabidopsis. Plant J. 2010, 64, 151-164. [CrossRef]

81. Kwon, S.I.; Cho, H.J.; Kim, S.R.; Park, O.K. The Rab GTPase RabG3b Positively regulates autophagy and immunity-associated hypersensitive cell death in Arabidopsis. Plant Physiol. 2013, 161, 1722-1736. [CrossRef]

82. Zientara-Rytter, K.; Sirko, A. To deliver or to degrade-An interplay of the ubiquitin-proteasome system, autophagy and vesicular transport in plants. FEBS J. 2016, 283, 3534-3555. [CrossRef] [PubMed]

83. Yoshimoto, K.; Ohsumi, Y. Unveiling the molecular mechanisms of plant autophagy—From autophagosomes to vacuoles in plants. Plant Cell. Physiol. 2018, 59, 1337-1344. [CrossRef] [PubMed]

84. Parzych, K.R.; Klionsky, D.J. An overview of autophagy: Morphology, mechanism, and regulation. Antioxid. Redox Signal. 2014, 20, 460-473. [CrossRef] [PubMed]

85. Marion, J.; Le Bars, R.; Besse, L.; Batoko, H.; Satiat-Jeunemaitre, B. Multiscale and multimodal approaches to study autophagy in model plants. Cells 2018, 7, 5. [CrossRef]

86. Chanoca, A.; Kovinich, N.; Burkel, B.; Stecha, S.; Bohorquez-Restrepo, A.; Ueda, T.; Otegui, M.S. Anthocyanin vacuolar inclusions form by a microautophagy mechanism. Plant Cell 2015, 27, 2545-2559. [CrossRef] 
87. Mizushima, N.; Noda, T.; Yoshimori, T.; Tanaka, Y.; Ishii, T.; George, M.D.; Ohsumi, Y. A protein conjugation system essential for autophagy. Nature 1998, 395, 395-398. [CrossRef]

88. Li, W.; Li, J.; Bao, J. Microautophagy: Lesser-known self-eating. Cell Mol. Life Sci. 2012, 69, 1125-1136. [CrossRef]

89. Uttenweiler, A.; Schwarz, H.; Mayer, A. Microautophagic vacuole invagination requires calmodulin in a $\mathrm{Ca}^{2+}$ independent function. J. Biol. Chem. 2005, 280, 33289-33297. [CrossRef]

90. Mijaljica, D.; Prescott, M.; Devenish, R.J. Microautophagy in mammalian cells: Revisiting a 40-year-old conundrum. Autophagy 2011, 7, 673-682. [CrossRef]

91. Sattler, T.; Mayer, A. Cell-free reconstitution of microautophagic vacuole invagination and vesicle formation. J. Cell Biol. 2000, 151, 529-538. [CrossRef]

92. Suzuki, K.; Ohsumi, Y. Molecular machinery of autophagosome formation in yeast, Saccharomyces cerevisiae. FEBS Lett. 2007, 581, 2156-2161. [CrossRef] [PubMed]

93. Geng, J.; Klionsky, D.J. The Atg8 and Atg12 ubiquitin-like conjugation systems in macroautophagy. 'Protein modifications: Beyond the usual suspects' review series. EMBO Rep. 2008, 9, 859-864. [CrossRef] [PubMed]

94. Hanada, T.; Noda, N.N.; Satomi, Y.; Ichimura, Y.; Fujioka, Y.; Takao, T.; Ohsumi, Y. The Atg12-Atg5 Conjugate has a novel E3-like activity for protein lipidation in autophagy. J. Biol. Chem. 2007, 282, 37298-37302. [CrossRef] [PubMed]

95. Xie, Z.; Klionsky, D.J. Autophagosome formation: Core machinery and adaptations. Nat. Cell. Biol. 2007, 9, 1102-1109. [CrossRef]

96. Uttenweiler, A.; Schwarz, H.; Neumann, H.; Mayer, A. The vacuolar transporter chaperone (VTC) complex is required for microautophagy. Mol. Biol. Cell 2007, 18, 166-175. [CrossRef]

97. Uttenweiler, A.; Mayer, A. Microautophagy in the yeast Saccharomyces cerevisiae. Methods Mol. Biol. 2008, 445, 245-259.

98. Borek, S.; Stefaniak, S.; Śliwiński, J.; Garnczarska, M.; Pietrowska-Borek, M. Autophagic machinery of plant peroxisomes. Int. J. Mol. Sci. 2019, 20, 4754. [CrossRef]

99. Chang, T.; Schroder, L.A.; Thomson, J.M.; Klocman, A.S.; Tomasini, A.J.; Stromhaug, P.E.; Dunn, W.A. PpATG9 encodes a novel membrane protein that traffics to vacuolar membranes, which sequester peroxisomes during pexophagy in Pichia pastoris. Mol. Biol. Cell 2005, 16, 4941-4953. [CrossRef]

100. Mukaiyama, H.; Baba, M.; Osumi, M.; Aoyagi, S.; Kato, N.; Ohsumi, Y.; Sakai, Y. Modification of a ubiquitin-like protein Paz2 conducted micropexophagy through formation of a novel membrane structure. Mol. Biol. Cell 2004, 15, 58-70. [CrossRef]

101. Manjithaya, R.; Nazarko, T.Y.; Farré, J.C.; Subramani, S. Molecular mechanism and physiological role of pexophagy. FEBS Lett. 2010, 584, 1367-1373. [CrossRef]

102. Nazarko, V.Y.; Nazarko, T.Y.; Farre, J.C.; Stasyk, O.V.; Warnecke, D.; Ulaszewski, S. Atg35, a micropexophagy-specific protein that regulates micropexophagic apparatus formation in Pichia pastoris. Autophagy 2011, 7, 375-385. [CrossRef] [PubMed]

103. Sakai, Y.; Oku, M.; van der Klei, I.J.; Kiel, J.A. Pexophagy: Autophagic degradation of peroxisomes. Biochim. Biophys. Acta 2006, 1763, 1767-1775. [CrossRef] [PubMed]

104. Ichimura, Y.; Kirisako, T.; Takao, T.; Satomi, Y.; Shimonishi, Y.; Ishihara, N.; Mizushima, N.; Tanida, I.; Kominami, E.; Ohsumi, M.; et al. A ubiquitin-like system mediates protein lipidation. Nature 2000, 408, 488-492. [CrossRef]

105. Farré, J.C.; Manjithaya, R.; Mathewson, R.D.; Subramani, S. PpAtg30 tags peroxisomes for turnover by selective autophagy. Dev. Cell 2008, 14, 365-376. [CrossRef] [PubMed]

106. Tamura, N.; Oku, M.; Sakai, Y. Atg8 regulates vacuolar membrane dynamics in a lipidation-independent manner in Pichia pastoris. J. Cell Sci. 2010, 123, 4107-4116. [CrossRef] [PubMed]

107. Nazarko, T.Y.; Ozeki, K.; Till, A.; Ramakrishnan, G.; Lotfi, P.; Yan, M.; Subramani, S. Peroxisomal Atg37 binds Atg30 or palmitoyl-CoA to regulate phagophore formation during pexophagy. J. Cell Biol. 2014, 204, 541-557. [CrossRef]

108. Kissova, I.; Salin, B.; Schaeffer, J.; Bhatia, S.; Manon, S.; Camougrand, N. Selective and non-selective autophagic degradation of mitochondria in yeast. Autophagy 2007, 3, 329-336. [CrossRef]

109. Bhatia-Kiššová, I.; Camougrand, N. Mitophagy in yeast: Actors and physiological roles. FEMS Yeast Res. 2010, 10, 1023-1034. [CrossRef] 
110. Kanki, T.; Klionsky, D.J. Mitophagy in yeast occurs through a selective mechanism. J. Biol. Chem. 2008, 283, 32386-32393. [CrossRef]

111. Rahman, M.A.; Mostofa, M.G.; Ushimaru, T. The Nem1/Spo7-Pah1/lipin axis is required for autophagy induction after TORC1 inactivation. FEBS J. 2018, 285, 1840-1860. [CrossRef]

112. Krick, R.; Muehe, Y.; Prick, T.; Bremer, S.; Schlotterhose, P.; Eskelinen, E.L. Piecemeal microautophagy of the nucleus requires the core macroautophagy genes. Mol. Biol. Cell. 2008, 19, 4492-4505. [CrossRef] [PubMed]

113. Luo, M.; Zhao, X.; Song, Y.; Cheng, H.; Zhou, R. Nuclear autophagy: An evolutionarily conserved mechanism of nuclear degradation in the cytoplasm. Autophagy 2016, 12, 1973-1983. [CrossRef] [PubMed]

114. Mijaljica, D.; Devenish, R.J. Nucleophagy at a glance. J. Cell Sci. 2013, 126, 4325-4330. [CrossRef] [PubMed]

115. Takeshige, K.; Baba, M.; Tsuboi, S.; Noda, T.; Ohsumi, Y. Autophagy in yeast demonstrated with proteinase-deficient mutants and conditions for its induction. J. Cell Biol. 1992, 119, 301-311. [CrossRef]

116. Thompson, A.R.; Vierstra, R.D. Autophagic recycling: Lessons from yeast help define the process in plants. Curr. Opin. Plant Biol. 2005, 8, 165-173. [CrossRef]

117. Teter, S.A.; Eggerton, K.P.; Scott, S.V.; Kim, J.; Fischer, A.M.; Klionsky, D.J. Degradation of lipid vesicles in the yeast vacuole requires function of Cvt17, a putative lipase. J. Biol. Chem. 2001, 276, 2083-2087. [CrossRef]

118. Epple, U.D.; Suriapranata, I.; Eskelinen, E.L.; Thumm, M. Aut5/Cvt17p, a putative lipase essential for disintegration of autophagic bodies inside the vacuole. J. Bacteriol. 2001, 183, 5942-5955. [CrossRef]

119. Maeda, Y.; Oku, M.; Sakai, Y. A defect of the vacuolar putative lipase Atg15 accelerates degradation of lipid droplets through lipolysis. Autophagy 2015, 11, 1247-1258. [CrossRef]

120. Ramya, V.; Rajasekharan, R. ATG15 encodes a phospholipase and is transcriptionally regulated by YAP1 in Saccharomyces cerevisiae. FEBS Lett. 2016, 590, 3155-3167. [CrossRef]

121. Shimamura, H.; Nagano, M.; Nakajima, K.; Toshima, J.Y.; Toshima, J. Rab5-independent activation and function of yeast Rab7-like protein, Ypt7p, in the AP-3 pathway. PLoS ONE 2019, 14, e0210223. [CrossRef]

122. Suriapranata, I.; Epple, U.D.; Bernreuther, D.; Bredschneider, M.; Sovarasteanu, K.; Thumm, M. The breakdown of autophagic vesicles inside the vacuole depends on Aut4p. J. Cell Sci. 2000, 113, 4025-4033. [PubMed]

123. Yang, Z.; Huang, J.; Geng, J.; Nair, U.; Klionsky, D.J. Atg22 Recycles Amino Acids to Link the Degradative and Recycling Functions of Autophagy. Mol Biol Cell. 2006, 17, 5094-5104. [CrossRef] [PubMed]

124. Yang, Z.; Klionsky, D.J. Permeases recycle amino acids resulting from autophagy. Autophagy 2007, 3, $149-150$. [CrossRef] [PubMed]

125. Nishida, I.; Watanabe, D.; Tsolmonbaatar, A.; Kaino, T.; Ohtsu, I.; Takagi, H. Vacuolar amino acid transporters upregulated by exogenous proline and involved in cellular localization of proline in Saccharomyces cerevisiae. J. Gen. Appl. Microbiol. 2016, 62, 132-139. [CrossRef] [PubMed]

126. Sekito, T.; Chardwiriyapreecha, S.; Sugimoto, N.; Ishimoto, M.; Kawano-Kawada, M.; Kakinuma, Y. Vacuolar transporter Avt4 is involved in excretion of basic amino acids from the vacuoles of Saccharomyces cerevisiae. Biosci. Biotechnol. Biochem. 2014, 78, 969-975. [CrossRef]

127. Rojo, E.; Zouhar, J.; Carter, C.; Kovaleva, V.; Raikhel, N.V. A unique mechanism for protein processing and degradation in Arabidopsis thaliana. Proc. Natl. Acad. Sci. USA 2003, 100, 7389-7394. [CrossRef]

128. Fujiki, Y.; Teshima, H.; Kashiwao, S.; Kawano-Kawada, M.; Ohsumi, Y.; Kakinuma, Y.; Sekito, T. Functional identification of AtAVT3, a family of vacuolar amino acid transporters, in Arabidopsis. FEBS Lett. 2017, 591, 5-15. [CrossRef]

129. Delorme-Axford, E.; Klionsky, D.J. Transcriptional and post-transcriptional regulation of autophagy in the yeast Saccharomyces cerevisiae. J. Biol. Chem. 2018, 293, 5396-5403. [CrossRef]

130. Janse van Rensburg, H.C.; Van den Ende, W.; Signorelli, S. Autophagy in plants: Both a puppet and a puppet master of sugars. Front. Plant Sci. 2019, 10, 14. [CrossRef]

131. Yang, M.; Bu, F.; Huang, W.; Chen, L. Multiple regulatory levels shape autophagy activity in plants. Front. Plant Sci. 2019, 10, 532. [CrossRef]

132. Avin-Wittenberg, T.; Honig, A.; Galili, G. Variations on a theme: Plant autophagy in comparison to yeast and mammals. Protoplasma 2012, 249, 285-299. [CrossRef] [PubMed]

133. Borek, S.; Paluch-Lubawa, E.; Pukacka, S.; Pietrowska-Borek, M.; Ratajczak, L. Asparagine slows down the breakdown of storage lipid and degradation of autophagic bodies in sugar-starved embryo axes of germinating lupin seeds. J. Plant Physiol. 2017, 209, 51-67. [CrossRef] [PubMed] 
134. Díaz-Troya, S.; Pérez-Pérez, M.E.; Florencio, F.J.; Crespo, J.L. The role of TOR in autophagy regulation from yeast to plants and mammals. Autophagy 2008, 4, 851-865. [CrossRef] [PubMed]

135. Efeyan, A.; Sabatini, D.M. mTOR and cancer: Many loops in one pathway. Curr. Opin. Cell Biol. 2010, 22, 169-176. [CrossRef]

136. Meijer, A.J.; Lorin, S.; Blommaart, E.F.; Codogno, P. Regulation of autophagy by amino acids and MTOR-dependent signal transduction. Curr. Opin. Cell Biol. 2010, 22, 169-176. [CrossRef]

137. Onodera, J.; Ohsumi, Y. Autophagy is required for maintenance of amino acid levels and protein synthesis under nitrogen starvation. J. Biol. Chem. 2005, 280, 31582-31586. [CrossRef]

138. Borek, S.; Kubala, S.; Kubala, S.; Ratajczak, L. Comparative study of storage compound breakdown in germinating seeds of three lupine species. Acta Physiol. Plant. 2011, 33, 1953-1968. [CrossRef]

139. Borek, S.; Pukacka, S.; Michalski, K. Regulation by sucrose of storage compounds breakdown in germinating seeds of yellow lupine (Lupinus luteus L.), white lupine (Lupinus albus L.) and Andean lupine (Lupinus mutabilis Sweet). II. Mobilization of storage lipid. Acta Physiol. Plant. 2012, 34, 1199-1206. [CrossRef]

140. Borek, S.; Ratajczak, W.; Ratajczak, L. Regulation of storage lipid metabolism in developing and germinating lupin (Lupinus spp.) seeds. Acta Physiol. Plant. 2015, 37, 119. [CrossRef]

(C) 2020 by the authors. Licensee MDPI, Basel, Switzerland. This article is an open access article distributed under the terms and conditions of the Creative Commons Attribution (CC BY) license (http://creativecommons.org/licenses/by/4.0/). 